\title{
CODE MIXING AND CODE SWITCHING FOUND IN VIDEO INSTAGRAM
}

\author{
Siti Nita Kartika ${ }^{1}$, Ratri Harida ${ }^{2}$, Adip Arifin ${ }^{3}$ \\ Fakultas Bahasa dan Seni, STKP PGRI Ponorogo \\ ${ }^{1}$ tika.kartika95@gmail.com, ${ }^{2}$ ratri3rida@gmail.com, ${ }^{3}$ adiparifin@yahoo.com
}

\begin{abstract}
Abstrak
Penelitian ini bertujuan untuk menganalisis ujaran Baby Moonella yang mengandung campur kode dan alih kode di video Instagram miliknya. Ada 5 video yang dipilih dengan mempertimbangkan kecukupan representasi penggunaan alih kode dan campur kode kekinian. Penelitian ini menggunakan metode deskriptif kualitatif. Data dikumpulkan dari hasil transkripsi tuturan Baby Moonella. Untuk menganalisis data, peneliti menggunakan teori dari Hymes (1986) dan Siregar (1996) yang diadaptasi dari Hoffman. Hasil dari penelitian ini menunjukkan ada tiga jenis alih kode dan dua jenis campur kode yang digunakan Baby Monella, seperti: tag code switching, inter-sentential switching, intra-sentential switching, intra-sentential mixings, insertion in extra-sentential mixing, dan alternation in Extra-sentential mixing. Jenis yang paling dominan digunakan dalam tutur kata Baby Moonella yaitu intra-sentential switching dan extra-sentential mixing dalam bentuk alternation. Alasan Baby Moonella melakukan pencampuran kode dan alih kode karena dia meniru apa yang dikatakan ibunya. Dia sering merasa kebingungan dengan perubahan bahasa dalam percakapan sehari-harinya. Banyak kata dalam Bahasa Inggris yang dia sendiri tidak mengetahui arti dan padanannya dalam Bahasa Indonesia. Selain itu, Baby Moonella juga sudah dibiasakan oleh orang tuanya untuk menggunakan dua bahasa dalam komunikasi sehari-hari.
\end{abstract}

Kata Kunci: alih kode, campur kode, video instagram, Babby Moonella

\begin{abstract}
This study focused on analyzing Baby Moonella's utterances which contained code mixing and code switching in her Instagram videos. There were 5 selected videos chosen which adequately represented the the realization of code switching and code mixing. This research employed qualitative descriptive method. The data were collected from Baby Moonella's transcription. To analyze the data, the researcher used Hymes (1964) and Siregar (1996) theory, adapted from Hoffman. The result showed that there were three types of code switching and two types of code mixing used by Baby Moonella, such as: tag code switchings, inter-sentential switching, intrasentential switchings, intra-sentential mixings, insertions in extra-sentential mixing, and alternations in Extra-sentential mixing. The dominant type used was intra-sentential switching and extra-sentential mixing in alternation form. The reason Baby Moonella did code mixing and code switching because she imitated what her mom had said. She often confused with the language change in the conversation she involved in. besides, she didn't know the meaning of many English words in Indonesian. Furthermore, she has been accustomed to use bilingual in her daily conversation.
\end{abstract}

Keywords: code switching, code mixing, Instagram videos, Baby Moonella 


\section{INTRODUCTION}

In this era, everyone can communicate in more than one language freely. Nowadays, it may usual hearing speakers used two or even three languages in a communication event. Speakers often switch and mix one language to another language in purpose. In the language study, this phenomenon is called code mixing and code switching. The realization of code mixing and code switching appears in various forms, such as oral and written communication, face to face communication, online communication, and so forth.

Wardaugh (1998: 103) argued that "code mixing occurs when conversation use both languages together to the extent that they change from one language to the other in the course of a single utterance." It means that the speaker changes some of the language elements (i.e. word) within the utterance. In the other hand, code switching according to (Hymess, 1986) code-switching had become a common term for alternative use of two or more language, or varieties of language, or even speech styles. Sociolinguistics as generally deals with the study of society and language relationship views the phenomenon as something acceptable in communication. Speakers have their own rights to use any language, as long as the communication can run well though uses more than one language. Finegan (1994: 3) stated that "in using language people do not always use the standard language to make people understood what the speaker meant. People sometimes use language variation which is to show their identity." Speakers prefer to change language because of the specific purpose. When interlocutors cannot understand what the speakers mean, they usually change the language to make them understand.

In their development, Siregar (1996: 50) adapted from Hoffman's theory (1991) categorized code mixing into intra-sentential mixing and extra-sentential mixing. Intrasentential mixing is the alternation of single words of phrases to clauses within a single sentence or utterance, for example: "Kamu harus bersemangat, jangan give up gitu." (give up as code mixing of word in the sentence). Extra-sentential mixing is mixing two languages in single sentence, which divided more into insertion, alternation, and congruent lexicalization. Structurally, extra-sentential mixing is less complex of syntactic construction. For the detail, the example of each can be observed below:

Insertion: Jangan nge-judge orang dari penampilan saja.

(judge is an English word inserted in the Indonesian utterance).

Alternation: Aku bekerja every day. Kalau malemnya I'm sleepy ya wajar lah.

(The underlined words above realized in the syntactic structure)

Congruent Lexicalization: Gee mi a hug (give me a hug)

(different lexical shared in grammar structure)

In case of code switching, Hymes (1986) divided into three types; tag code switching, inter-sentential switching, and intra-sentential switching. Tag code switching occurs when a bilingual speaker inserts short expressions (tag) from different language at the end of his/her utterances, such as: An Indonesian bilingual switches from English to Indonesian, "It's okay, no problem, ya nggak? " Inter-sentential code switching occurs when there is complete sentence in a foreign language uttered between two sentences in a base language, for instance: An Indonesian bilingual switches from Indonesian to English, "Mereka pemain kawakan di film itu. They're oldies but goodies, they say. Yang pasti, masih enak ditonton". Intra-sentential switching is realized when a word, a phrase, or a clause, of a foreign language is found within the sentence in a base language, example: An Indonesian switches to Javanese, "Baru saja pulang, tapi disuruh berangkat 
lagi, kapan lerenku?" (I just get home, but you order me to go again, when do I take a rest?

In fact, code mixing and code switching is often uttered by various age levels, including youngster or children, for instance Baby Moonella. She is an influencer of Indonesian children who likes to use code switching or code mixing in her utterance. In her very young age, she has been getting 1.2 million followers. The little girl who born in August 2014 is not an artist, her parents are not artist also nor join in the potency artist management groups. Baby Moonella is better known as the Instagram influencer who is attractive. Due to her various actions uploaded in the social media, she is often invited at various programs on television station. Observing her videos, Babby Moonella shows her awesome linguistics intelligence which characterized by the use of language effectively to express herself rhetorically or poetically (Arifin, 2016).

The researcher reason took Baby Moonella as the object of this research because she is four years old who has ability to speak more than one language. Her mother tongue is Indonesia, but she often inserts English words in her speaking, especially with her mother or other family members. The topic of conversation is commonly talking about Moonella's daily activities at home, school and other places.

Regarding to the use of social media, the realization of code mixing and code switching in nowadays era has found so many. Users can easily express meanings, intention, story, and ideas to attract other social media users to involve in his/her activity or status (often in the form of language event). The other users are commonly involved in by giving comment, questioning, criticizing, mocking, or just liking. As a result, the more users involved in such kind of mass communication, the more popular the account owner will be. It is then truly undeniable that language becomes the most important medium for expressing feelings and exchanging meanings in human life (Arifin, 2018).

Furthermore, everyone can get information easily through social media, such as Instagram, Facebook, Twitter, Youtube and many more. In those media the users often found public figures or some well-known people who use code switching or code mixing when they speak. These phenomena are not only found in the real life but also in the media of videos or pictures with caption, such as in Instagram. It is one of many media which is popular among social media users at present. Similar with Facebook or Twitter, everyone who creates an Instagram account has a profile and news feed. When the account owner posts a picture or video, it will be displayed on his/her profile. In language study, this phenomenon is appropriately addressed through Sociolinguistics.

So far, studies on code mixing and code switching have been conducted by many Indonesian researchers (see Margana, 2016; Sari, 2013; Rahmania, 2016; and Wakhidah and Sudaryanto, 2019), but the study on analyzing both code mixing and code switching by taking the videos Instagram as the source of data is found rare. Therefore, considering the importance of code mixing and code switching in language study, therefore, this study is intensively aimed at finding out their realization in Instagram videos used by Baby Moonella in Instagram. Furthermore, this study is also intended to know the dominant type of code mixing and code switching as well as to explain the reason for using code switching and code mixing in Baby Moonella's Instagram.

\section{RESEARCH METHOD}

In the present study, the researcher used descriptive qualitative method. The object of this research is Baby Moonella's videos on her Instagram. The researcher analyzed 5 selected videos from her Instagram account. Those five videos were definitely 
contained the realization of code switching and code mixing. Data collecting technique was performed through documentary technique. Researchers transcribed Baby Moonella's utterances which contained code mixing and code switching. Thus, the form of data was descriptive which involved word, phrase, clause, and sentence. To analyze the data, interactive model, as suggested by Miles and Hubberman (1994) is applied. In analyzing the data, Hymes (1964) and Siregar (1996) is used to classify and interpret the findings

\section{RESULT AND DISCUSSION}

In this part, the writer explains and discusses the research findings. The discussion closely relates with some relevant theories on both code mixing and code switching. There were many Indonesian-English of code mixing and code switching found by the researcher. The detail findings are presented in the following table.

Table 1: Baby Moonella's code mixing and code switching in her five videos

\begin{tabular}{llll}
\hline \multicolumn{1}{c}{ Code Switching } & \multicolumn{2}{c}{ Code Mixing } & Total \\
\hline \multicolumn{1}{c}{ Type } & \multicolumn{2}{c}{ Total } & 3 \\
& 5 & Intra-sentential mixing & \\
& & Extra-sentential mixing: & 2 \\
Tag code switching & 1. Insertion & 6 \\
Inter-sentential switching & 1 & $2 . \quad$ Alternation & 0 \\
Intra-sentential switching & & $3 . \quad$ Congruent lexicalization & \\
\hline
\end{tabular}

The total number of utterance which contained the code mixing and code switching in Baby Moonella's videos on Instagram, were: five tag code switchings, one inter-sentential code switching, nine intra-sentential code switchings, three intrasentential code mixings, two insertions, six alternations, and no congruent lexicalization. Based on the type of code switching and code mixing the researchers found the dominant type used in Baby Moonella's utterance is intra-sentential switching (nine data). The findings confirmed that result of previous studies (see Margana, 2016; Sari, 2013; and Rahmania, 2016) which also displayed the intra-sentential switching found most.

In general, the findings mean that many Indonesians tend to switch the language because mostly Indonesians are bilingual speaker. As known in Indonesian context, the country has one national language (Bahasa Indonesia) and more than 800 living ethnic languages (ethnologue.com). Therefore, it is something common if Indonesian speakers switch and mix their languages from the mother tongue into second language, and vice versa. The goal of switching and mixing language of course varies according to their intended purpose, for instance: to emphasize the point of communication, to make utterance easier to understand, to create intimacy, to situate the communication, to realize implied meaning, and so forth.

\section{Code Switching}

As explain in the previous part, the classification on code switching type was based on Hymes' theory (1986). He categorized code switching into three types, namely tag code switching, inter-sentential switching, and intra-sentential switching. The 
findings which represent the use of those three types of code switching are presented in the following part.

\section{Tag code switching}

A tag code switching happens when a bilingual insert short expressions (tag) from different language at the end of his/her utterances. Based on the findings, there are five data which could be categorized as tag code switching, as in the following way:

\section{Utterance 1: Moonel, pengen angry.}

Based on Baby Moonella's utterance, the word angry is categorized as tag code switching because Baby Moonella inserted short expression from different (foreign) language at the end of her utterances. As widely known, the word angry is an English word, which means marah Indonesian. Moonella wants to say "Moonel pengen marah". She switched her language because her mommy gave her a question in Indonesian and then continued in English. Mommy said "Moonel sad, happy atau apa?", In Indonesian means "Moonel sedih, senang atau apa?". Referring to Hymes theory, Moonella switched her utterance in regard to the key factor of letting other (her mom) knows her feelings. This video took place on Baby Moonella's way to school on February $22^{\text {th }}, 2019$ with the duration of 1.59 minutes.

\section{Utterance 2: Bagus yeah.}

In the second utterance yeah is an English word, in Indonesian means ya. Moonella wanted to say in Bahasa Indonesia, bagus, yal tentu to answer her mom question, Hayooh raportnya Moonel bagus nggak? She answered Bagus, yeah to make sure her mom if her grade was good. Based on Hymes theory, Baby Moonella switched her utterance in regard to the participant factor. It was because she spoke more informal to her mom. This video took place on her way to school on March $12^{\text {th }}, 2019$. The duration of this video is 01.57 minutes.

\section{Utterance 3: Moonel cry.}

In the third utterance cry is an English word, in Indonesian means menangis. Her Mommy stated to Moonel "enggak, mommy cinta Moonel banget malahan. Kan mommy sayang banget sama Moonel". Moonel answered her mom spontaneously by adding English word in her utterance as usually she did. In this case, Baby Moonella switched her utterance in regard to the key factor, which means she wanted her mother knowing her feeling exactly. This video took place at home on February $22^{\text {th }}, 2019$. The duration of this video was 2 minutes.

\section{Utterance 4: Moonel enggak suka worm.}

In the fourth utterance worm is an English word, in Indonesian means cacing. In this video, Baby Moonella and her brother made a video unboxing slime worm. In the slime, there were some fake worms. Moonella told her mother that she didn't like worm in Bahasa Indonesia, Moonel enggak suka cacing. By uttering this, Moonella switched her utterance in regard to the participant factor. It happened due to the situational and unchanging topic of conversation. This video took place at home on May 20th, 2019. The duration of this video was 01.35 minutes.

\section{Utterance 5: Tumpah!, It's okay Cocon.}

In the last utterance which categorized as tag code switching, Moonella's brother, named Marson spilled the slime on the table and then directly Moonella said Tumpah, it's okay Cocon, which means "Tumpah, enggak apa-apa Cocon" in Bahasa Indonesia. This script was found in the same video as the fourth utterance. The use of foreign structure within a sentence as Hymes conceptualized, belongs to tag code switching. Moonella 
purposively switched her utterance in regard to the act sequence factor due to the use of careful and calm speaking to her brother in order to make him relax and not panic. This video took place at home on May $20^{\text {th }}, 2019$. The duration of this video was 01.35 minutes.

\section{Inter-sentential switching}

Inter-sentential code switching occurs when there are complete sentence in a foreign language uttered between two sentences in a base language. Based on the findings, there was only one data which could be categorized as an intra-sentential switching, as follows:

\section{Utterance: Look at the worm! Jangan pegang Cocon.}

The sentence Look at the worm is an English word, in Bahasa Indonesia means Lihat cacing itu. Baby Moonella warned her brother for not touching the slime, because there were some fake worms in it. For the change in the sentence, it included intersentential switching because the speaker changed her language in the other language after the speaker spoke in bahasa Indonesia to English. The interlocutor will be easy to understand what the speaker says though the speaker uses two languages in the same sentence. Based on Hymes theory, Baby Moonella switched her utterance in regard to the setting and scene factor which characterized by the natural situation.

\section{Intra-sentential switching}

Intra-sentential switching is found when a word, a phrase, or a clause, of a foreign language is found within the sentence in a base language. Based on the findings, there was nine data which could be categorized as an intra-sentential switching. Based on the findings, Baby Moonella inserted some word, phrase or sentence of foreign language into her base language. It means Baby Moonella used intra-sentential switching. As in presented in the following part:

\section{Utterance 1: Dia bilang, I don't like you again.}

In the first utterance I don't like you again is an English sentence, in Bahasa Indonesia means Saya tidak menyukaimu lagi. In this video, the speaker talked about Moonella's best friends at school. Her mommy asked to Moonella Kenapa Jayden enggak suka Moonel lagi? (Why didn't Jayden like Moonel anymore?). Then Moonella answered her mom's question in Bahasa Indonesia continued in English. This video took place on the way of her school on February $22^{\text {th }}, 2019$. The duration of this video was 2 minutes. In this case, Baby Moonella switched her utterance in regard to the key factor. It was because she wanted her mom know her feeling. She wished her mother could catch the message she sent in the conversation.

\section{Utterance 2: I don't know.}

In the second utterance, the phrase $I$ don't know is classified as intra-code switching. In this video Baby Moonella switched her language to answer her mom's question Jadi gimana dong, Moonel sad?. Her mom gave question both in Bahasa Indonesia continued in English, then Baby Moonella answered in English I don't know means Saya tidak tahu. This video took place on her way to school on February 22th, 2019. The duration of this video was 2 minutes. Based on Hymes theory, Baby Moonella switched her utterance in regard to the key factor because the question from her mother was more sensitive. It was about her privacy.

\section{Utterance 3: Iya, almost for more page again.}

In the third utterance which contained intra-code switching was Iya, almost for more page again. In Indonesian means Iya, hampir untuk lebih banyak halaman lagi. In 
the utterance, Baby Moonella told her mom that her English book was almost done. In the previous dialogue, she told her mom if she got perfect score in English lesson. This video took place on her way to school on March $12^{\text {th }}, 2019$. The duration of this video was 01.57 minutes. Referring to Hymes theory, Baby Moonella switched her utterance in regard to the participants factor.

Utterance 4: No, this is almost three, and I already, Oh ya four.

In the fourth utterance which contained intra-code switching was No, this is almost three. And I already. Oh ya four. In Indonesian lexically means Tidak, ini hampir tiga. Dan saya sudah. Oh iya empat. Baby moonella answered her mom question Iya? for more page? Emang Moonel udah belajar apa aja sih?. This dialogue was on the same video as the previous dialogue. This video took place on her way school on March $12^{\text {th }}, 2019$. The duration of this video was 01.57 minutes. Referring to Hymes theory, Baby Moonella switches her utterance in regard to the participant factor.

\section{Utterance 5: Nothing, a cheese.}

In the fifth utterance, Moonella realized intra-code switching by saying Nothing, a cheese. Here, Moonella's utterance was in an English phrase to answer her mom's question. It means Tidak ada, keju. The question from her mom was on Bahasa Indonesia. Then Baby Moonella answered it clearly by using English words. This script was on the same video as the third and fourth script. This video took place on her way school on March 12 $2^{\text {th }}, 2019$. The duration of this video was 01.57 minutes. Baby Moonella answered in carefully. Based on Hymes theory, Baby Moonella switched her utterance in regard to the act sequence factor.

\section{Utterance 6: Nope.}

In the sixth utterance Nope means enggak. This script was on the same video with the previous script. This video took place at on the way to school on March 12th, 2019. The duration of this video was 01.57 minutes. Baby Moonella answered carefully. According to Hymes, Baby Moonella switched her utterance in regard to the participant factor because she spoke in more casual to her mother.

\section{Utterance 7: Haloo.. squishy humberger for my dad.}

In the seventh utterance, Moonella uttered words showing the use of intra-code switching. In the opening of the video, Baby Moonella said Hi to the camera in Bahasa Indonesia continued in English to introduce her new toys. In Bahasa Indonesia means Halo, hamburger lembut untuk ayahku. This video took place at home on May 20th, 2019. The duration of this video was 01.35 minutes. Referring to the Hymes' theory, Baby Moonella switched her utterance in regard to the act sequence factor because she spoke carefully with a nice opening and continued showing a replica of hamburger to the audiences on the camera.

\section{Utterance 8: Wow, a big baby bubble.}

The above utterance represented the use of intra-code switching found in the same video as the previous. This video took place at home on May $20^{\text {th }}, 2019$. The duration of this video was 01.35 minutes. Referring to the Hymes' theory, Baby Moonella switched her utterance in regard to the setting and scene factor because when someone speak one language in one situation or natural situation which intended to influence people for choosing the code.

\section{Utterance 9: Haaaaa? Pokoknya buat four for you aunty uncle.}

In the last utterance Haaaaa? Pokoknya buat four for you aunty uncle. Baby Moonella promoted her new product (cookies). She called her followers with aunty-uncle. In Bahasa Indonesia means Haah? pokoknya buat empat (gratis kue yummy box) untuk 
tante dan paman. This video took place at home on April $10^{\text {th }}, 2019$. The duration of this video was 01.35 minutes. Referring to Hymes' theory, Baby Moonella switched her utterance in regard to the participant factor, because she spoke more casual to make her audience understand what she talked about.

\section{Code Mixing}

Code mixing is used to refer to a more general form of language contact that may include cases of code switching and the other form of contacts which emphasized the lexical items. From the definitions, the difference between code mixing and code switching can be inferred. First, in code mixing bilingual people seem to apply some foreign words or phrases (piece of one language smaller than clause). Second, bilingual people are said to mix codes (but not switch from one to another) when the topic doesn't change, nor does the situation. According to Siregar (1996), there are two types of code mixing, namely intra-sentential mixing and extra-sentential mixing. The specific types of extra-sentential mixing then categorized into three; insertion, alternation, and congruent lexicalization. To discuss the findings on code mixing, data display and discussion will be presented orderly.

\section{Intra-sentential mixing}

Intra-sentential mixing is the alternation of single words of phrases to clauses within a single sentence or utterance. Based on the findings, there were three data (utterances) which could be categorized as intra-sentential mixing. They are as follows:

Utterance 1: Because Jayden enggak suka Moonel lagi.

Utterance 2: Iya makan cheese dong.

Utterance 3: Mommy enggak sayang Moonel.

As known, because, cheese, and Mommy are definitely English words. Baby Moonella mixed her language because her mother often asked her both in Bahasa Indonesia and English. That's why she answered in Bahasa Indonesia and then mixed in English as well. She would like to insert a single word or phrase when speaking. The phenomenon happened in above communication belongs to insertion, as a part of intrasentential mixing.

In the first utterance, because is basically an English word. Baby Moonella mixed her language because her mother often asked her in both Bahasa Indonesia and English. That's why she answered her mother's question in bahasa and English. She would like to insert a single word or phrase when speaking. Baby Moonella directly answered her mother's question more sensitively because it was about her feeling. Referring to Hymes theory, Baby Moonella mixed her utterance in regard to the key factor. This video took place at on the way to school on February $22^{\text {th }}, 2019$. The duration of this video was about 2 minutes.

In the second utterance cheese in Indonesian means keju. Baby Moonella did mixing because she thought her mom was curious about Moonella's health by questioning. She answered it directly with strong emphasis dong in Bahasa Indonesia. In this case, Baby Moonella mixed her utterance in regard to the ends factor. It happens because people do mixing to talk about a particular topic. This video took place on her way school on March $12^{\text {th }}, 2019$. The duration of this video was 2 minutes. While in the last utterance, the word Mommy is basically similar to Ibu or Bunda in Baha Indonesia. Baby Moonella already used the term Mommy to call her mother. In this case, Baby 
Moonella mixed her utterance in regard to the participant factor. This video took place at on the way to school on February $22^{\text {th }}, 2019$. The duration of this video was 2 minutes.

\section{Extra-sentential mixing}

Extra-sentential mixing is mixing two languages in a sentence. There are three forms of extra-sentential mixing; insertion, alternation, and congruent lexicalization. Based on the findings, there were two insertion forms and six alternation forms, and none form represent congruent lexicalization. The discussion on the findings is presented below.

\section{Insertion}

The insertion happens when the speaker inserts some Indonesian language in English word when speaking.

Utterance 1: English book-nya

Utterance 2: Iih ada worm-nya nggak?

In the first utterance above, Baby Moonella mixed her utterance in regard to the participants factor, because the topic was dealing with Moonella's progress in school. Baby Moonella did insertion in her utterance to make sure her mom understands what she meant. The video took place at on the way to school on March $12^{\text {th }}, 2019$. The duration of this video was 01.57 minutes. While in the second utterance which contained insertion form was about unboxing the slime. Moonella asked to her mother to make sure if there was no worm by questioning Iiih, ada worm-nya nggak? In this case, Baby Moonella mixed her utterance in regard to the participant factor because in the given situation Baby Moonella scared of worm. She then asked her mom as usually by using informal/ casual language. She did mixing to make sure her mom understood what she meant. This video took place at home on May $20^{\text {th }}, 2019$. The duration of this video was 01.35 minutes.

\section{Alternation}

The alternation happens when the speaker do alternation between structure of languages. Furthermore, Muysken (2000: 3) argued that alternation occurs when structures of two languages are alternated indistinctively both at the grammatical and lexical level between structures and from languages. Six identified utterances which belong to alternation are presented below:

Utterance 1: Mommy, English book-nya Moonel almost ten.

Utterance 2: Dia because cute, dia little. Jadi dia sukain Mommy. Terus Mommy nggak sayang Moonel

Utterance 3: Aunty-uncle, besok Moonella yummy box ada yang baru cemilannya. Utterance 4: Moonel udah cobain aslinnya yummy bangeeeeeettt, aunty uncle.

Utterance 5: Haaaaa? Pokoknya buat four for you aunty uncle. Aunty uncle mau ngga?

Utterance 6: Kalo Moonel and wjtour bikin give away. Polling ya.

In the first utterance, Mommy English book-nya Moonel almost ten, the alternation happens when the speaker alternates between structures of languages. Referring to Hymes' theory, Baby Moonella mixed her utterance in regard to participant factor, because the topic was talked about Moonellas's progress at school. Baby Moonella did alternation in her utterance because she felt more comfortable by using two different languages when speaking. The video took place at on the way to school on March $12^{\text {th }}$, 2019. The duration of this video was 01.57 minutes. 
In the second utterance, "Dia because cute, dia little. Jadi dia sukain Mommy. Terus Mommy nggak sayang Moonel", Baby Moonella mixed her utterance in regard to the participant factor, because the topic was talked about Moonellas's progress in school. Baby Moonella did insertion in her utterance to make sure her mom's understand what she meant. This video took place on her way to school on February $22^{\text {th }}$, 2019. The duration of this video was 2 minutes. As in the second utterance, Babby Moonella also uttered the alternation form due to the participant factor as shown in the last (sixth) utterance. She did it because she imitated her mom and spoke more informal way to make the audience understand what she meant.

In third utterance, Aunty-uncle besok Moonella yummy box, ada yang baru cemilannya. Referring to Hymes theory, Baby Moonella did alternation in her utterance in regard to the act sequence factor. It happened because Baby Moonella more comfortable used two language when speaking. This video took place at home on April $10^{\text {th }}, 2018$. The duration of this video was 2 minutes.

In the fourth utterance which contained alternation was Moonel udah cobain aslinnya yummy bangeeeeeettt aunty uncle. In this case, Baby Moonella did alternation in regard to the act sequence factor. It happened because Baby Moonella felt more comfortable by using two languages when speaking. This video took place at home on February $22^{\text {th }}, 2019$. The duration of this video was 2 minutes. While in the fifth utterance had alternation was Haaaaa??? Pokoknya buat four for you aunty uncle. Aunty uncle mau nggak?. In this case Baby Moonella did alternation in regard to the act sequence factor. Baby Moonella spoke carefully to the audience in her camera. This video took place at home on February $22^{\text {th }}, 2019$. The duration of this video was 2 minutes.

\section{CONCLUSION}

From the analysis and discussion as presented in the previous part, it can be concluded that the five selected videos of Baby Moonella contained code mixing and code switching which dominated by the change of Indonesian language to English and vice versa. Quantitatively, there were three types of code switching and two types of code mixing used by Baby Moonella, such as: five tag code switchings, one inter-sentential switching, nine intra-sentential switchings, three intra-sentential mixings, two insertions in extra-sentential mixing, and six alternations in Extra-sentential mixing. The dominant type used was intra-sentential switching and extra-sentential mixing in alternation form. The reason Baby Moonella did code mixing and code switching because she imitated what her mom had said. She often confused with the language change in the conversation she involved in. Besides, she didn't know the meaning of many English words in Indonesian. Furthermore, she has been accustomed to use bilingual in her daily conversation.

\section{REFERENCES}

Arifin, A. (2016). Recognizing the students' intelligences earlier. Deiksis, 08(03), 217225. https://doi.org/10.30998/deiksis.v8i03.691

Arifin, A. (2018). How non-native writers realize their interpersonal meaning? Lingua Cultura, 12(May), 155-161. https://doi.org/10.21512/lc.v12i2.3729

Finegan, D. B. E. (1994). Sociolinguistics perspective on register. New York: Oxford University Press. 
Hoffman, C. (1991). An introduction to bilingualism. New York: Longman.

Hymes, D. (1986). Directions in sociolinguistic: The ethnography of communication. Oxford: Blackwell.

Margana. (2016). Alih kode dalam proses pembelajaran bahasa Inggris di SMA. Litera, 12(1), 39-52. https://doi.org/https://doi.org/10.21831/ltr.v12i01.1324

Muysken, P. (2000). Bilingual speech: A typology of code mixing. Cambridge: Cambridge University Press.

Rahmania, N. A. (2016). Code switching used by Kimmy Jayanti 'Ilook' Program on Net $T V$. Thesis: Maulana Malik Ibrahim Islamic State University.

Sari, D. M. (2013). An analysis code switching and code mixing used in a talk show hitam putih.

Siregar, B. U. (1996). Code alternation-in bilingual speech behavior. University of North Sumatera.

Wakhidah, S., \& Sudaryanto. (2019). Analisis campur kode dalam iklan daring Lazada edisi April 2019: Kajian Sosiolinguistik. Deiksis, 11(03), 269-275. https://doi.org/10.30998/deiksis.v11i03.3852

Wardaugh., R. 1998. A. I. to S. N. Y. B. (1998). An introduction to sociolinguistics. New York: Blackwell. 